\title{
A Comparative Analysis of Mother Language Teaching Curricula of Turkey, Singapore and Ireland
}

\author{
Research Article
}

\section{Emine Seda KOC ${ }^{1}$}

${ }^{1}$ Namik Kemal University, Department of Child Development, Tekirda ğ, Turkey, ORCID: 0000-0003-1656-8808

To cite this article: Koc, E. S. (2020). A Comparative Analysis of Mother Language Teaching Curricula of Turkey, Singapore and Ireland, International Online Journal of Educational Sciences, 12 (3), 10-28.

\begin{tabular}{l} 
ARTICLE INF \\
\hline Article History: \\
Received: 30.01 .2020 \\
Available online: \\
16.06.2020
\end{tabular}

ARTICLE INFO

\begin{abstract}
Reading, which takes parts at comprehension dimension of a language, is one of the basic skills that is necessary for learning. In this study, it is aimed to analyze the mother language teaching curricula that are the major tools for bringing in this skill and accordingly the curricula of Turkey, Singapore and Ireland have been analyzed in accordance with PIRLS reading skills. This study, that is an example for qualitative research, has been conducted in accordance with case study model and document analysis method has been used for analyzing the curricula. According to the findings of the study, It has been concluded that the majority of the attainments identified as similar to the PIRLS skills in the mother language curriculum of Turkey is associated with low levels of skills and there are 3 attainments related to the high-level reading skills. It is concluded that there is not any attainments in the curriculum that overlaps with intermediate or advanced reading skills. It has also determined that in the Singapore mother language curriculum, different skills for each level are included and similarly mostly high and advanced skills are included in the in Ireland's 1999 and 2016 mother language curricula.
\end{abstract}

(C) 2020 IOJES. All rights reserved

Keywords:

Reading, Mother language teaching, PIRLS skills

\section{Introduction}

Reading is an interactive process consisting of inferring, knowing correct sounds and comprehension (Kamhi \& Catts, 2008). It can also defined as an idea exchange process between the reader and the writer, in which the reader tries to understand the text and tries to bring new meanings by combining these understandings from texts with his prior knowledge (Akyol, 2007). After this exchange process, readers can gain new information, ideas, insights and perspectives. In addition to these cognitive achievements, reading brings together affective contributions that can help individuals enjoy pleasure, have virtue by maturing, decorate their minds and relax.

${ }^{1}$ Corresponding author's address: Namık Kemal University

e-mail:eskoc@nku.edu.tr

DOI: https://doi.org/10.15345/iojes.2020.03.002 
Reading has many social, economic, cultural and psychological dimensions. People may read to increase their knowledge in their profession, meet practical needs, follow current events, increase their intellectual abilities, develop their special interests, meet their religious needs, spend their free time and to create personal satisfaction and pleasure (Özçelebi and Cebecioğlu, 1990). In other words, reading is one of the main tools that help individuals to meet their multidirectional needs.

Reading basically consists of two processes as recognizing words and understanding text (Pang, Muaka, Bernhardt and Kamil, 2003). Accordingly, it is not enough for individuals to only recognize and voice written symbols during the reading process. In order to talk about a meaningful and successful reading process, the ingredients included in the text can be interpreted and they must be associated with past learning and mental acquisitions by individuals and accordingly a judgment and conclusion must be made. As can be seen, reading is a holistic and progressive skill that should be considered with comprehension and involves more than one mental activity.

Reading skills are among the dominant language skills acquired in the primary education process that are necessary for learning to be realized. Reading, "... is the ability to understand and use written language forms required by the community and/or needed by the individual. Readers can build meaning from different types of text. They read to learn, join the community of readers in school and everyday life or to have fun."(Mullis, Martin \& Sainsbury, 2015). As can be seen in the definition, the emphasis on reading skill is not reading fluency, but reading comprehension. There are different types of reading, including digital reading, and reading skill requires an active, meaningful and social process. This skill, which can be described as a prerequisite for the academic success of individuals, is also considered important for the realization of lifelong learning. In fact, it is stated that at the end of the 3rd grade, children who could not acquire the reading skills required by their ages are at great risk for school failure. The results of a long study conducted in America for about 40 years confirm this information and state that the difference between students who have not acquired these skills and those who have acquired these skills is as distinct as the difference between a high school graduate student and a student who left high school (Hernandez, 2012). This information clearly demonstrates that it is meaningful and important to reach these skills in the first years of education-training processes, besides reading skills. Especially reading skills and diversity that are gained at a young age has a very important effect on the mental development and social maturation of individuals (Russel, 1949: 16). As none of the students fail in elementary education, the students having reading difficulties pass their classes; yet, they cannot perform reading at the level expected of their grade; hence, they experience various problems such as anxiety and depression throughout their schooling. Moreover, they cannot get the help needed to resolve their problems and they experience adaptation problems in their classes (Bender, 2012). For this reason, it is important to gain the ability to read and comprehension through formal education processes in a solid and at the right time in order to train successful students and qualified literacy. Although reading skill is not specific to any discipline, undoubtedly the biggest responsibility and duty in this matter falls into the mother language education processes applied in schools

Mother language education is a process that is laid out spontaneously and informally in the first years of life and is carried out within the scope of planned and regular activities since the day the individual started school. Mother language education process has rules in itself and is successful when acting in accordance with these rules (Mert, 2012). Through this process, it is aimed to develop and regulate the language skills of individuals within certain rules.

Mother language education process is based on comprehension and expression skills. Native and true use of the mother language will be possible with the effective functionalization of the education of the skills of comprehension reading, listening, speaking and writing (Önkaş, 2010). Mother language education refers 
to any form of schooling that makes use of the language or languages that children are most familiar with. usually the language that children speak at home with their family (Singh et al., 2019).

The main purpose of mother language education is to develop comprehension power, bring in expressive skill and habit, create listening and reading habit and pleasure, enrich personal active and passive vocabulary, teach basic grammar rules and form language awareness and liking (Kavcar, Oğuzkan \& Sever, 1995). Although there are many variables that are decisive for the realization of these goals, there are undoubtedly important duties for the curriculums applied in the learning processes because the curriculum is the main reference point for the textbooks and activities to be organized in the learning-teaching processes.

Since reading is not a skill specific to any discipline, an interdisciplinary study is necessary for learning processes to become qualified and sufficient to fulfill the objectives set for mother language education. Therefore, it is expected that all the curricula will contain elements that will support language development. Apart from this general feature expected from the curricula, it is doubtless that some special responsibilities fall to the Turkish course, which has the main purpose of "making students like Turkish language, perceiving and adopting its rules and directing students to use Turkish with awareness and care in the development process" (MEB, 2015), and to the curriculum of this course. Accordingly, it is expected that the relevant curriculum will be designed in accordance with the characteristics and structure of Turkish, it will include elements that support the mother language education and development process, and it will include methods and techniques that improve the reading and reading comprehension skills, which are the basic skills that will enable students to identify their environment by progressing in language and thought

Accurate and complete acquisition of reading comprehension skills is very important for individuals to reach the learning outcomes expected from them. However, in addition to whether these skills are acquired by the students or not, the level of attaining these skills should also be determined. In line with this understanding, the International Association for the Evaluation of Educational Achievement, with its more familiar name, has been conducting studies on the international level for more than 50 years to evaluate the reading skills and the factors affecting the acquisition of these skills at an international level. In this way, it is possible to see the status of students' success levels across the country, as well as information about the place among other countries (Rutkowski, Gonzalez, Joncas \& von Davier, 2010).

One of these studies, PIRLS (Progress in International Reading Literacy Study) provides a comparative evaluation of the reading comprehension skills of 4th grade students in participating countries on an international scale every 5 years since 2001. Unlike other international studies, PIRLS, which is focused solely on reading skills, has also included a new title called ePIRLS since 2016. Accordingly, it is aimed to determine the online reading skills of students by taking into consideration computer literacy, which is one of the 21st century skills through ePIRLS.

The average scores of the countries participating in PIRLS reveal the general performance of the countries compared to other participants and do not provide information about the regional distribution of the scores within the countries. Thus, while one of the two countries with similar averages has students with a higher number of average scores, the other one can have a larger number of low or high score student populations (Ogle, Sen, Pahlke, Jocelyn, Kastberg, Roey, and Williams, 2003). According to this, in PIRLS, it is understood that the average success rate of the countries is not significant, but the regional success levels of the countries is meaningful. These data, presented in PIRLS, allow students to monitor the change and development of their reading skills over the years. In this respect, the PIRLS project provides important feedback for evaluating the education policies and the curriculum being implemented in the participating countries. It is known that Turkey joined the project of PIRLS in in 2001 but did not take place in 2006, 2011 and 2016. Instead, since 2000, Turkey participates in the PISA project, which is carried out every three years 
in order to determine the knowledge and skills of students aged 15 years in reading skills, mathematics literacy and science literacy.

Considering that the acquisition of reading skills in an appropriate and correct way since the first years of compulsory education has a direct impact on students' success both in Turkish lessons and in other fields, it can be said that the results obtained with the PIRLS project, which was conducted only in the primary school period for the evaluation of this skill, and which is focused only on reading skills, contain highly functional data. PISA data, which allows to obtain relatively more comprehensive results in this respect, are very valuable in the name of Turkey's education policies, but this project is implemented in the later years of compulsory education process and therefore Turkey do not have the opportunity to be compared at international level reading skills of elementary school since there is no up-to-date data available; and this is seen as a major deficiency.

Due to reasons that have been expressed, it is anticipated that the examination of the Primary School Turkish Course Curriculum, which is the mother language teaching curriculum currently being implemented in Turkey, in terms of the basic reading competencies included in the PIRLS content will provide important feedback in order to review the curriculum from a different perspective. In addition, it is thought that examining the mother language teaching curricula of Singapore (2nd in PIRLS 2016) and Ireland (4th in PIRLS 2016), which are two countries with high level of success in the project notably in 2016, in terms of PIRLS skills and making comparisons between countries will enable curriculum development and evaluation studies to be carried out from an international perspective. It is also predicted that by examining the reading skills included in the Turkish Course Curriculum and revealing the aspects open to improvement, if any, will enrich the curriculum and contribute to the achievement of the course objectives.

In line with this purpose, answers to the following questions were sought in the research.

1. What are the similarities and differences between attainments of the Turkey mother language education curriculum and PIRLS reading skills?

2. What are the similarities and differences between the objectives of the Singapore mother language curriculum and the PIRLS reading skills?

3. What are the similarities and differences between the objectives of the Irish mother language curriculum and the PIRLS reading skills?

\section{Method}

\section{Research Model}

This research, which is an example of qualitative research, was conducted according to the case study model. Qualitative research is a type of research in which qualitative data collection methods such as observation, interview and document analysis are used and perceived; a process for realizing the events in a realistic and holistic manner is followed. In other words, qualitative research is an approach that prioritizes researching and understanding social phenomena in the environment in which they depend, with an understanding based on creating theory (Ylldirım, 1999). Case study is a qualitative research approach in which the researcher examines one or more conditions limited over time with data collection tools (observations, interviews, audiovisuals, documents, reports), and situations and thematic themes are defined (Creswell, 2007). In this study, Turkey, Singapore and Ireland context of mother language education curricula are taken as cases and tried to be examined systematically within the scope of research questions.

While conducting such examinations, in order to ensure the reliability of the findings obtained in the study, in other words to make confirmations; the nature of the qualitative research model was taken into account. In qualitative research, validity and reliability are handled differently from quantitative studies 
(Yıldırım \& Şimşek, 2013). Instead of the validity and reliability expressions used in quantitative research, expressions such as credibility in the qualitative research, the accuracy of the results and the competence of the researcher are used (Krefting, 1991). There are many methods used to increase the credibility of qualitative research. These can be listed as long-term interaction, participant confirmation and expert review (Holloway \& Wheeler, 1996). In accordance with the method and research questions used in this study, expert examination was used to increase the credibility and accuracy of the results. Accordingly, the opinions of the two field experts were taken before the achievements determined to be similar to PIRLS skills were presented in the study. Both experts are asked to compare their studies on native language teaching curricula from different countries. Following the expert review, the results were examined comparatively by the researcher and after the necessary corrections were made, the final findings were interpreted and presented.

\section{Data Sources}

Turkey, Singapore and Ireland mother language teaching curricula are the data sources used in this study. In determining the countries to be compared in the study, the scores that countries have received in PIRLS in the previous years are considered as the determinants. Accordingly, when 2016 PIRLS results and 2011 PIRLS results were analyzed together, it was seen that Singapore and Ireland concurringly increased their successes and Singapore rose from 4th to 2nd place and Ireland increased from 10th to 4th place. Although there are many different variables that can be effective in these achievements of the countries, it is a fact that the most basic element determining the quality of the said processes is the curriculum which is guided in the planning and implementation of the education-training processes. For this reason, by examining the curriculum that is thought to contribute significantly to the successful scorecards of the said countries, it was tried to obtain tips and feedback regarding the curriculum development processes (PIRLS, 2016).

The curricula have been accessed through the official websites of the countries and they have been examined comparatively within the scope of PIRLS reading skills. As the 2018-2019 academic year in which the research was carried out due to the gradual curriculum transition process in Ireland, both curricula were handled during the comparison process. Since the name of the curriculum is frequently used in the study, TMLTC (Turkey Mother Language Teaching Curriculum) SMLTC (Singapore Mother Language Teaching Curriculum) and IMLTC (Ireland Mother Language Teaching Curriculum) abbreviations were sometimes used to avoid repetition.

\section{Data Analysis}

In the study, document analysis method was used in the analysis of curricula. The document analysis, which is used in the vast majority of qualitative research, includes the analysis of written materials that contain information about the phenomenon or cases intended to be investigated (Madge, 1965). This method makes it possible to analyze the documents produced in a certain time frame about a research problem or documents produced by more than one source and at different intervals based on a wide timeframe (Yildırım \& Şimşek, 2013). In this study, the curricula that used as documents were examined within the framework of research questions and the findings obtained were interpreted and presented.

\section{Findings}

Before comparing the curriculums in terms of PIRLS skills, it would be correct to review these skills. Accordingly, it is seen that reading skills in PIRLS are dealt with under the title of "international benchmarks" and presented in 4 different levels within the scope of literary and informational texts. Skills determined within the scope of the project are listed as follows;

1.Low International Benchmark

When reading predominantly simpler Literary Texts, students can: 
- Locate and retrieve explicitly stated information, actions, or ideas

- Make straightforward inferences about events and reasons for actions

- Begin to interpret story events and central ideas.

When reading predominantly simpler Informational Texts, students can:

- Locate and reproduce explicitly stated information from text and other formats (e.g., charts, diagrams)

-Begin to make straightforward inferences about explanations, actions, and descriptions

2.Intermediate International Benchmark

When reading a mix of simpler and relatively complex Literary Texts, students can:

- Independently locate, recognize, and reproduce explicitly stated actions, events, and feelings

- Make straightforward inferences about the attributes, feelings, and motivations of main characters

- Interpret obvious reasons and causes, recognize evidence, and give examples

- Begin to recognize language choices

When reading a mix of simpler and relatively complex Informational Texts, students can:

- Locate and reproduce two or three pieces of information from text

- Make straightforward inferences to provide factual explanations

- Begin to interpret and integrate information to order events

3.High International Benchmark

When reading relatively complex Literary Texts, students can:

- Locate and distinguish significant actions and details embedded across the text

- Make inferences to explain relationships between intentions, actions, events, feelings and give text-based support

- Interpret and integrate story events and character actions, traits, and feelings as they develop across the text

- Recognize the use of some language features (e.g., metaphor, tone, imagery)

When reading relatively complex Informational Texts, students can:

- Locate and distinguish relevant information within a dense text or a complex table

- Make inferences about logical connections to provide explanations and reasons

- Integrate textual and visual information to interpret the relationship between ideas

- Evaluate and make generalizations about content and textual elements.

4.Advanced International Benchmark

When reading relatively complex Literary Texts, students can: 
- Interpret story events and character actions to describe reasons, motivations, feelings, and character development with full text-based support

- Begin to evaluate the effect on the reader of the author's language and style choices

When reading relatively complex Informational Texts, students can:

- Distinguish and interpret complex information from different parts of text, and provide full text based support

- Integrate information across a text to explain relationships and sequence activities

- Begin to evaluate visual and textual elements to consider the author's point of view (PIRLS, 2016).

The similarities and differences between the attainments of Turkey Mother Language Teaching Curriculum and PIRLS reading skills

When the skills in Turkey Mother Language Teaching Curriculum were examined, it was seen that the curriculum was divided into four skill areas as "listening/watching, speaking, reading and writing" and the reading area that is related to PIRLS skills was divided into three areas as "fluent reading, vocabulary and comprehension". The attainments in the curriculum were grouped according to these skill areas and presented under different titles according to their class levels. Since it was determined that the majority of the attainments were shared in different grade levels, a holistic approach was preferred in the comparison and presentation of the PIRLS reading skills and the attainments. Accordingly, it was determined that there was no attainment in TMLTC that meet PIRLS reading skills exactly but that there were some attainments partially overlapping or similar to those skills. These attainments and related PIRLS skills are presented in Table 1.

Table1. The Attainments in Turkey Mother Language Teaching Curriculum and similar PIRLS Skills

\begin{tabular}{|c|c|}
\hline $\begin{array}{l}\text { The Attainments in Turkey Mother Language } \\
\text { Teaching Curriculum }\end{array}$ & PIRLS skills identified to be similar \\
\hline \multicolumn{2}{|l|}{ Answers questions about the text. (1st Class) } \\
\hline $\begin{array}{l}\text { Tells what he reads. (1st-2nd-3rd Classes) } \\
\text { Determines the subject of the text. (1st Class) }\end{array}$ & $\begin{array}{l}\text { Locate and retrieve explicitly stated information, } \\
\text { actions, or ideas. (Low) }\end{array}$ \\
\hline \multirow{2}{*}{\multicolumn{2}{|c|}{$\begin{array}{l}\text { Determines the subject of the text he reads. (2nd- } \\
\text { 3rd.4th Classes) }\end{array}$}} \\
\hline & \\
\hline \multirow{2}{*}{\multicolumn{2}{|c|}{$\begin{array}{l}\text { Answers questions about the text he reads. (2nd- } \\
\text { 3rd.4th Classes) }\end{array}$}} \\
\hline & \\
\hline \multicolumn{2}{|l|}{$\begin{array}{l}\text { Determines the main idea/main feeling of the } \\
\text { text. (3th- } 4 \text { th Classes) }\end{array}$} \\
\hline \multicolumn{2}{|l|}{$\begin{array}{l}\text { Determines the story elements in the text he } \\
\text { reads. ( } 2 \text { nd-3rd.4th Classes) }\end{array}$} \\
\hline $\begin{array}{l}\text { Makes inferences about what he reads. (3rd } \\
\text { Class) }\end{array}$ & $\begin{array}{l}\text { Make straightforward inferences about events and } \\
\text { reasons for actions. (Low) } \\
\text { Begin to make straightforward inferences about } \\
\text { explanations, actions, and descriptions. (Low) }\end{array}$ \\
\hline $\begin{array}{l}\text { Makes inferences about what he reads. (4th } \\
\text { Class) } \\
\text { Inferences such as cause-effect, comparison, } \\
\text { analogy and sampling are provided. }\end{array}$ & $\begin{array}{l}\text { Make inferences to explain relationships between } \\
\text { intentions, actions, events, and feelings, and give text- } \\
\text { based support. (High) }\end{array}$ \\
\hline $\begin{array}{l}\text { Compares the characteristics of the heroes in the } \\
\text { text he reads. ( } 4 \text { th Class) }\end{array}$ & $\begin{array}{l}\text { Interpret and integrate story events and character } \\
\text { actions, traits, and feelings as they develop }\end{array}$ \\
\hline
\end{tabular}




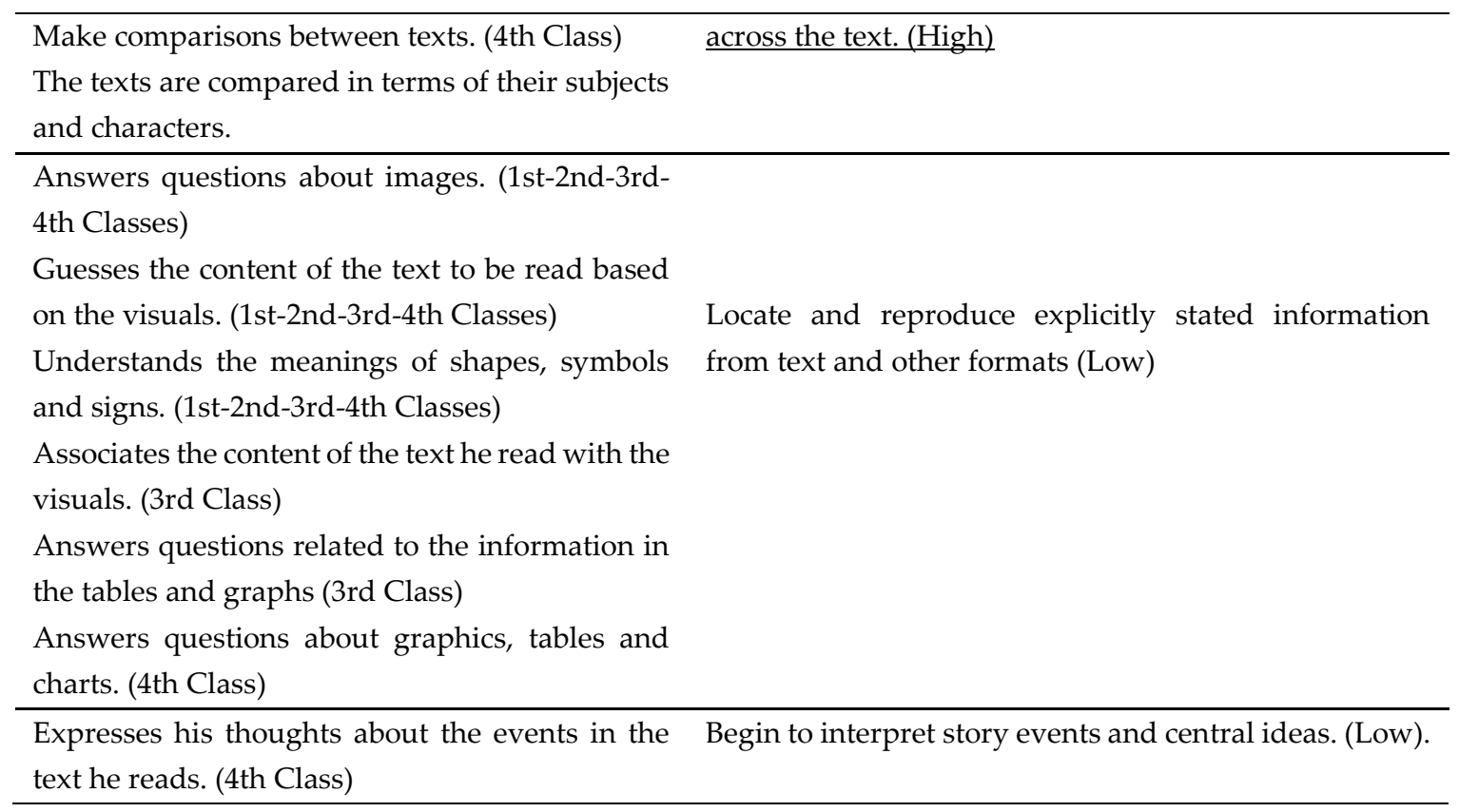

When Table 1 is examined, it is seen that the attainments presented at different grade levels, which aimed students to understand the text they read correctly, were the ones that are most similar to the PIRLS skills. Similarly, the attainments presented for understanding the visuals, tables and graphics again overlap with reading skills. When the levels of the skills correspond with the attainments were examined, it is noteworthy that skills given underlined were high-level and all other skills were low-level skills; attainments that are similar to any of the intermediate or advanced reading skills are not included in the curriculum. Accordingly, it can be said that the achievements in TMLTC significantly overlap with some of the PIRLS skills, but they have some deficiencies in meeting these skills completely.

Similarities and differences between the objectives of the Singapore Mother Language Curriculum and the PIRLS reading skills

When the objectives in the Singapore Mother Language Curriculum were analyzed, it was seen that the objectives were presented within six learning areas: Listening and Monitoring, Reading and Monitoring, Speaking and Presentation, Writing and Presentation, Grammar, Vocabulary. It is noteworthy that in the curriculum, each learning area was divided into titles called as "Focus Areas" and these titles are divided into sub-titles. The "Reading and Monitoring" focus area and sub-titles determined that was related to scope of PIRLS skills are as follows;

Reading and Monitoring

A Reading Comprehension and Tracking Skills, Strategies, Attitudes and Behaviors

- Starting Reading

- Closed Reading and Monitoring

- Critical Reading, Monitoring and Awareness

Reading and Watching Different Types of Rich Texts

- Reading and Monitoring Literary Texts

- Reading and Monitoring Informative / Functional Texts

Wide Reading and Monitoring 
- Wide Range of Reading and Monitoring (SMLTC, 2010).

When the curriculum objectives given under the titles presented above were analyzed, it was determined that some objectives were common in different grade levels, as in TMLTC. When the curriculum objectives were compared with the PIRLS skills, it was seen that there were no overlapping objective expressions but there were objectives that meet the skills to a great extent. According to PIRLS skill levels related to these objectives, they can be listed as follows;

Table2. The Objectives in Singapore Mother Language Teaching Curriculum and similar PIRLS Skills

\begin{tabular}{|c|c|}
\hline $\begin{array}{l}\text { The Objectives in Singapore Mother Language } \\
\text { Teaching Curriculum }\end{array}$ & PIRLS skills identified to be similar \\
\hline $\begin{array}{l}\text { Makes inferences from the visuals (pictures, } \\
\text { diagrams, graphics, tables, maps, etc.). (1st-2nd- } \\
\text { 3rd-4th Classes) }\end{array}$ & $\begin{array}{l}\text { Locate and reproduce explicitly stated information } \\
\text { from text and other formats. (Low) }\end{array}$ \\
\hline $\begin{array}{l}\text { Makes inferences based on clues in images or text. } \\
\text { (1st-2nd-3rd-4th Classes) }\end{array}$ & $\begin{array}{l}\text { Locate and retrieve explicitly stated information, } \\
\text { actions, or ideas. (Low) } \\
\text { Locate and reproduce explicitly stated information } \\
\text { from text and other formats (Low) } \\
\text { Begin to make straightforward inferences about } \\
\text { explanations, actions, and descriptions (Low) }\end{array}$ \\
\hline $\begin{array}{l}\text { Determines the introduction, development and } \\
\text { result of the stories. (1st-2nd Classes) } \\
\text { Tells the main event in the story. (1st-2nd-3rd-4th } \\
\text { Classes) } \\
\text { Identifies the simple elements in the story. (1st- } \\
\text { 2nd-3rd-4th Classes) }\end{array}$ & Begin to interpret story events and central ideas. (Low) \\
\hline $\begin{array}{l}\text { Notices regulatory examples in a text (result of } \\
\text { events, cause-effect, etc.). (4th Class) }\end{array}$ & $\begin{array}{l}\text { Make straightforward inferences about events and } \\
\text { reasons for actions. (Low) } \\
\text { Interpret obvious reasons and causes, recognize } \\
\text { evidence, and give examples. (Intermediate) }\end{array}$ \\
\hline $\begin{array}{l}\text { Distinguishes between cause and effect. (4th Class } \\
\text { ) }\end{array}$ & $\begin{array}{l}\text { Interpret obvious reasons and causes, recognize } \\
\text { evidence, and give examples. (Intermediate) }\end{array}$ \\
\hline $\begin{array}{l}\text { Separates and compares two or more ideas, texts, } \\
\text { topics. ( } 4 \text { th Class) }\end{array}$ & $\begin{array}{l}\text { Locate and reproduce two or three pieces of } \\
\text { information from text. (Intermediate) }\end{array}$ \\
\hline $\begin{array}{l}\text { Recognizes the variety in language use of the } \\
\text { author. (4th Class) }\end{array}$ & Begin to recognize language choices. (Intermediate) \\
\hline $\begin{array}{l}\text { Tells the results of the events in the story. } \\
\text { (1st-2nd-3rd-4th Classes) } \\
\text { Tells the details in the story. (1st-2nd-3rd-4th } \\
\text { Classes) } \\
\text { Identifies the heroes and behaviors in the Story. } \\
\text { (2nd-3rd-4th Classes) }\end{array}$ & $\begin{array}{l}\text { Make straightforward inferences about the attributes, } \\
\text { feelings, and motivations of main characters. } \\
\text { (Intermediate) } \\
\text { Interpret and integrate story events and character } \\
\text { actions, traits, and feelings as they develop } \\
\text { across the text. (High) }\end{array}$ \\
\hline $\begin{array}{l}\text { Finds and uses key idea and key details. (1st-2nd- } \\
\text { 3rd-4th Classes) } \\
\text { Finds the details in the text. (1st-2nd-3rd-4th } \\
\text { Classes) } \\
\text { Categorizes the details in the text. (1st-2nd-3rd-4th } \\
\text { Classes) }\end{array}$ & $\begin{array}{l}\text { Locate and distinguish significant actions and details } \\
\text { embedded across the text. (High) }\end{array}$ \\
\hline
\end{tabular}




\begin{tabular}{|c|c|}
\hline $\begin{array}{l}\text { Draws conclusions based on key details, hints and } \\
\text { main idea. (3rd-4th Classes) }\end{array}$ & $\begin{array}{l}\text { Locate and distinguish significant actions and details } \\
\text { embedded across the text. (High) } \\
\text { Make inferences to explain relationships between } \\
\text { intentions, actions, events, and feelings, and give text- } \\
\text { based support. (High) }\end{array}$ \\
\hline $\begin{array}{l}\text { Makes simple generalizations by identifying main } \\
\text { idea, key details and examples from different } \\
\text { sources. (1st-2nd-3rd-4th Classes) }\end{array}$ & $\begin{array}{l}\text { Evaluate and make generalizations about content and } \\
\text { textual elements. (High) }\end{array}$ \\
\hline $\begin{array}{l}\text { Identifies the implicit idea, key idea and key } \\
\text { details. (4th Class) }\end{array}$ & $\begin{array}{l}\text { Locate and distinguish significant actions and details } \\
\text { embedded across the text. (High) }\end{array}$ \\
\hline $\begin{array}{l}\text { Retells a story, scores a book by telling his } \\
\text { ideas.(1st-2nd-3rd-4th Classes) }\end{array}$ & $\begin{array}{l}\text { Evaluate and make generalizations about content and } \\
\text { textual elements. (High) } \\
\text { Begin to evaluate visual and textual elements to } \\
\text { consider the author's point of view. (Advanced) }\end{array}$ \\
\hline $\begin{array}{l}\text { Analyzes the ideas, sequential events, cause-effect, } \\
\text { classification-comparison, problem-solutions in } \\
\text { the text. (1st-2nd-3rd-4th Classes) }\end{array}$ & $\begin{array}{l}\text { Interpret story events and character actions to describe } \\
\text { reasons, motivations, feelings and character } \\
\text { development with full text-based support. (Advanced) } \\
\text { Integrate information across a text to explain } \\
\text { relationships and sequence activities. (Advanced) }\end{array}$ \\
\hline $\begin{array}{l}\text { Interprets and combines information from } \\
\text { different sources. (4th Class) } \\
\end{array}$ & $\begin{array}{l}\text { Begin to interpret and integrate information to order } \\
\text { events. (Intermediate) }\end{array}$ \\
\hline $\begin{array}{l}\text { Makes questioning, simple criticism and personal } \\
\text { comments based on a text. (1st-2nd-3rd-4th } \\
\text { Classes) }\end{array}$ & $\begin{array}{l}\text { Interpret story events and character actions to describe } \\
\text { reasons, motivations, feelings and character } \\
\text { development with full text-based support. (Advanced) }\end{array}$ \\
\hline $\begin{array}{l}\text { Realizes how the use of the language of the author } \\
\text { differs according to the purpose of writing and the } \\
\text { reader. (4th Class) }\end{array}$ & $\begin{array}{l}\text { Begin to evaluate the effect on the reader of the author's } \\
\text { language and style choices. (Advanced) }\end{array}$ \\
\hline
\end{tabular}

As shown in Table 2, although all of the PIRLS reading skills were not met in SMLTC, there were different skills of each level in the curriculum. Considering the levels of these skills, it is noteworthy that all of the skills offered within the scope of low level and advanced criteria were included in the curriculum. Three of the intermediate skills and five of the higher skills were not included in the curriculum. Although there are some deficiencies in terms of these skills determined according to this, it can be said that the curriculum has a very competent content in meeting PIRLS skills.

\section{Similarities and differences between the objectives of the Ireland Mother Language Curriculum and the PIRLS reading} skills

By the year of 2019, two different curricula are implemented simultaneously in the Irish mother tongue education process. The first one is the curriculum implemented at primary school level since 1999. The other one is is the 2016 mother language curriculum, which has started to be implemented gradually at the 1st-2nd level and will completely replace the previous curriculum by 2020 . Both curricula were examined in the comparison process in order to handle the Irish mother tongue teaching process and the related curriculum as a whole. Since only the grade levels in practice were included in the content of the 2016 curriculum, the reviews of this curriculum were limited to the 1st and 2nd grade levels.

When 1999 Curriculum, which was the first of the curriculum, was considered; it was seen that the content was divided into learning areas; and each of these learning areas was divided into the units offered under the titles "Verbal Language, Reading and Writing" and the curriculum objectives were presented within 
the scope of these units (IMLTC, 1999). As a result of comparing the mentioned objectives with the PIRLS skills, the ones determined to be similar are presented in Table 3.

Table 3. The Objectives in Ireland Mother Language Teaching Curriculum and similar PIRLS Skills

The Objectives in Ireland Mother Language (1999)

Teaching Curriculum

Finds the information and shares it with others. (1st- Locate and retrieve explicitly stated information, 2nd Classes)

Uses the information in simple texts using the table and index. (1st-2nd Classes)

\section{PIRLS skills identified to be similar}

actions, or ideas. (Low)

Locate and reproduce explicitly stated

information from text and other formats (e.g.. charts, diagrams) (Low)

Develops reading comprehension skills such as Locate and distinguish significant actions and finding events and details in the text, interpreting the details embedded across the text. (High) facts, retelling the story. (1st-2nd Classes)

Expresses personal opinions about a book orally or in writing.(1st-2nd Classes)

Interpret and integrate story events and character actions, traits, and feelings as they develop across the text. (High)

Evaluate and make generalizations about content and textual elements. (High).

Responds to characters and events in a story through Interpret and integrate story events and character speech, discussion, writing, animation or visual arts.(1st-2nd Classes)

Continues to develop his responses to reading materials (story).(discussion, dance, poetry, writing, etc.) (3th-4th Classes) actions, traits, and feelings as they develop across the text. (High) Interpret story events and character actions to describe reasons, motivations, feelings, and character development with full text-based support. (Advanced)

\begin{tabular}{ll}
\hline $\begin{array}{l}\text { Participates in discussions about a book with teachers } \\
\text { and other people.(1st-2nd Classes) }\end{array}$ & $\begin{array}{l}\text { Evaluate and make generalizations about content } \\
\text { and textual elements. (High). }\end{array}$ \\
\hline $\begin{array}{l}\text { Understands the relationship between text and } \\
\text { images. (3th-4th Classes) }\end{array}$ & $\begin{array}{l}\text { Integrate textual and visual information to } \\
\text { interpret the relationship between ideas. (High) }\end{array}$ \\
\hline Improves the skills of accessing basic knowledge. & $\begin{array}{l}\text { Locate and reproduce explicitly stated } \\
\text { (table, index, graphic, text title etc.) (3th-4th Classes) } \\
\text { information from text and other formats (e.g., }\end{array}$ \\
\hline Talks about books. (characters, writer, events, etc.) & $\begin{array}{l}\text { Interpret and integrate story events and character } \\
\text { actions, traits, and feelings as they develop across } \\
\text { (3th-4th Classes) }\end{array}$ \\
$\begin{array}{l}\text { the text. (High) } \\
\text { Interpret story events and character actions to } \\
\text { describe reasons, motivations, feelings, and } \\
\text { character development with full text-based } \\
\text { support. (Advanced) } \\
\text { Begin to evaluate visual and textual elements to } \\
\text { consider the author's point of view. (Advanced) }\end{array}$ \\
$\begin{array}{l}\text { Distinguish and interpret complex information } \\
\text { from different parts of text, and } \\
\text { provide full text based support. (Advanced) }\end{array}$ \\
\hline Sees and discusses the difference between reading \\
texts. (3th-4th Classes)
\end{tabular}

As can be seen in Table 3, there is no objective statement in IMLTC that meets the PIRLS skills exactly like the curricula of other countries. When the objectives determined to be similar were examined, it can be seen that the majority of these objectives met high and advanced skills. It is noteworthy that the three objectives given underlined overlapped with low level PIRLS skills and any objective similar to intermediate skills was 
not included in the curriculum. Apart from this, the relatively low number of objective expressions that match PIRLS skills in the curriculum is another remarkable finding. Based on all these findings, it can be said that the Irish mother tongue curriculum has a limited number of objectives that meet predominantly high and advanced skills, but through these objectives mostly it was aimed to develop skills for students to analyze and interpret the text, story or book they read.

Another curriculum examined in the study is the 2016 mother language teaching curriculum, which was being implemented at the 1st and 2nd grade levels in the Irish mother tongue education process. The most striking difference in this curriculum, where the language teaching process was defined as a developmental process, was the flexibility of practice it offered to educators. The curriculum was divided into "verbal language, reading and writing" learning areas and a general objective statement named as "learning outcome" was included under each learning area. This objective was divided into eight sub-learning objectives, called "milestones", which were directed towards the same behavior. These milestones were named between a and $\mathrm{h}$, and teachers were expected to plan their learning level and determine which milestone they should start teaching before the process. In other words, considering the individual differences of the students in the curriculum, the instruction was asked to be carried out gradually accordingly, and the milestones of different levels were named as "progress steps". In the curriculum, no matter what stage the teaching started, it was also emphasized that the students should complete their language learning with the outcomes, the objectives expected to be achieved were clarified and the process was also clarified in terms of reaching the education besides the flexibility it provided its practitioners about where to start. Accordingly, students were expected to be at the level of milestones in the a-e range for the 1st grade level and in the d-h range for the 2nd grade. In other words, whichever milestone was started at the end of the 1st grade, it was expected that the learning would move to the $\mathrm{d}$ level and at the end of the 2nd grade, it was aimed to reach the top level $\mathrm{h}$ by learning from any level of $d$ and above (IMLTC, 2016). To clarify the curriculum systematic, an example of the presentation of the objectives as follows;

Table4. Reading area-progress steps in 2016 Irish Mother Language Teaching Curriculum

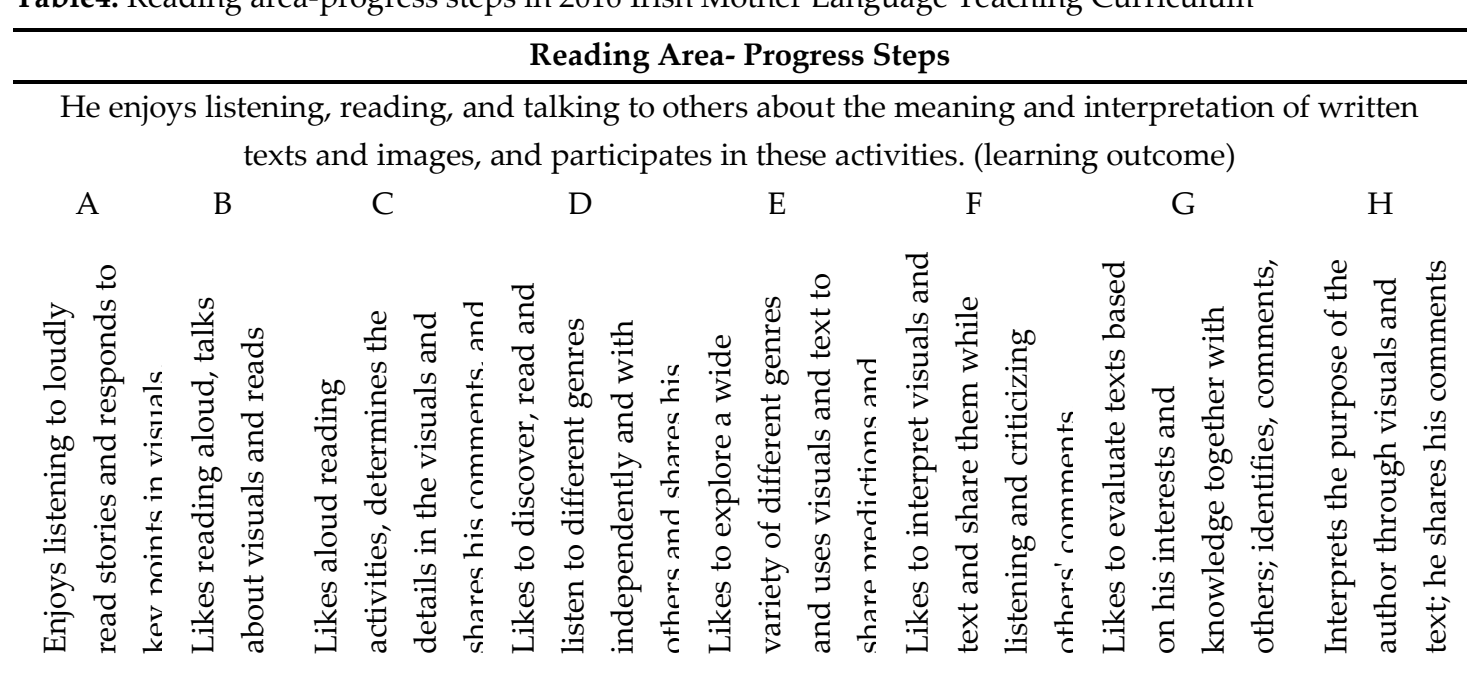

As can be seen from the example in Table 4, all the objectives in the curriculum were classified gradually and the learners were asked to reach the determined outputs gradually starting from the correct step during the implementation of the curriculum. When these objectives were analyzed with a holistic approach, the ones that are determined to be similar to PIRLS skills are as follows 
Table5. The Objectives in Ireland Mother Language Teaching Curriculum and similar PIRLS Skills

\begin{tabular}{|c|c|}
\hline $\begin{array}{l}\text { The Objectives in Ireland Mother Language } \\
\text { (2016) Teaching Curriculum }\end{array}$ & PIRLS skills identified to be similar \\
\hline $\begin{array}{l}\text { Interprets the purpose of the author through } \\
\text { visuals and text; shares his comments and defends } \\
\text { his opinion. (1st-2nd Classes/H) }\end{array}$ & $\begin{array}{l}\text { Begin to evaluate visual and textual elements to } \\
\text { consider the author's point of view. (Advanced) }\end{array}$ \\
\hline $\begin{array}{l}\text { Handles and evaluates the texts for a specific } \\
\text { purpose. (1st-2nd Classes/H) }\end{array}$ & $\begin{array}{l}\text { Distinguish and interpret complex information } \\
\text { from different parts of text and provide full text } \\
\text { based support. (Advanced) }\end{array}$ \\
\hline $\begin{array}{l}\text { Adds synonyms, heteronyms, antonyms and uses } \\
\text { its roots to understand foreign words. (1st-2nd } \\
\text { Classes/G) }\end{array}$ & $\begin{array}{l}\text { Recognize the use of some language features (e.g., } \\
\text { metaphor, tone, imagery). (High) }\end{array}$ \\
\hline $\begin{array}{l}\text { Starts reading the texts for specific purposes, } \\
\text { determines the difference between the texts, and } \\
\text { expresses their opinions and preferences about the } \\
\text { texts. (1st-2nd Classes/F) }\end{array}$ & $\begin{array}{l}\text { Evaluate and make generalizations about content } \\
\text { and textual elements. (High) }\end{array}$ \\
\hline $\begin{array}{l}\text { Uses the content elements in the texts to access } \\
\text { information. (1st-2nd Classes/F) } \\
\text { Uses lists and tables in the text to reach certain } \\
\text { information. (1st-2nd Classes/G) }\end{array}$ & $\begin{array}{l}\text { Locate and reproduce explicitly stated information } \\
\text { from text and other formats (e.g., charts, diagrams) } \\
\text { (Low) }\end{array}$ \\
\hline $\begin{array}{l}\text { Finds the appropriate information in the text and } \\
\text { realizes the emotional language in the text. (1st- } \\
\text { 2nd Classes/H) }\end{array}$ & $\begin{array}{l}\text { Locate and distinguish relevant information } \\
\text { within a dense text or a complex table. (High). }\end{array}$ \\
\hline $\begin{array}{l}\text { Finds the events in order by making use of the } \\
\text { visuals. (1st-2nd Classes/ B) }\end{array}$ & $\begin{array}{l}\text { Locate and retrieve explicitly stated information, } \\
\text { actions, or ideas. (Low) } \\
\text { Locate and reproduce explicitly stated } \\
\text { information from text and other formats (e.g., } \\
\text { charts, diagrams) (Low }\end{array}$ \\
\hline $\begin{array}{l}\text { Realizes the important information in the text and } \\
\text { tells the main points in the story in order. (1st-2nd } \\
\text { Classes/ E) }\end{array}$ & $\begin{array}{l}\text { Locate and retrieve explicitly stated information, } \\
\text { actions, or ideas. (Low) }\end{array}$ \\
\hline $\begin{array}{l}\text { Tells the main points in the story in key details. } \\
\text { (1st-2nd Classes / F) }\end{array}$ & $\begin{array}{l}\text { Begin to interpret story events and central ideas. } \\
\text { (Low) } \\
\text { Locate and distinguish significant actions and } \\
\text { details embedded across the text. (High) }\end{array}$ \\
\hline $\begin{array}{l}\text { It distinguishes unnecessary information in } \\
\text { different types of texts and underlines important } \\
\text { information and details and summarizes key } \\
\text { points in order. (1st-2nd Classes /G) }\end{array}$ & $\begin{array}{l}\text { Locate and distinguish significant actions and } \\
\text { details embedded across the text. (High) } \\
\text { Distinguish and interpret complex information } \\
\text { from different parts of text and provide full text } \\
\text { based support. (Advanced) } \\
\text { Integrate information across a text to explain } \\
\text { relationships and sequence activities. (Advanced) }\end{array}$ \\
\hline
\end{tabular}

When Table 5 is examined, it is seen that all but one of the objective expressions that were similar to PIRLS skills were in the objective group E and above. Considering the skills that correspond to these objectives, it is noteworthy that none of the intermediate skills were included in the curriculum as in the previous curriculum; mostly high and advanced skills were included in the content. Although the curriculum contain only a part of the PIRLS skills, considering that only 1 and 2 grade objectives were included in the content, it 
can be said that the Irish mother tongue curriculum may have competent content in terms of PIRLS skills, if these objectives, which are aimed at developing the high level skills of the learners, are complemented by goals containing different skills in the following grades.

\section{Discussion and Conclusion}

Reading is one of the basic skills that its foundation is laid in the first years of the formal education process and has a critical importance in learning and teaching experiences. PIRLS, is an international application that provides information on various factors such as school resources, teaching practices and curriculum related to this skill by examining the level and development over time for 4th grade students (Mullis, Martin, Kennedy and Foy, 2007). Through this application, it is aimed to evaluate the effects of education policies and practices of the countries on these skills by making comparisons at national and international levels (Mullis, Martin, Gonzalez and Kennedy, 2003).

In this study it was aimed to analyze the mother language teaching curricula of Singapore and Ireland, which have both achieved quite good results in the PIRLS project, and Turkey in terms of PIRLS reading skills and make comparisons between these curricula. As a result of the findings obtained in the study, it was determined that there was not any attainment/objective expression that corresponded with PIRLS skills in all three of the curriculum, but the attainments/objectives which were largely similar were included in the curricula. Accordingly, it was concluded that 18 achievements in TMLTC were similar to the PIRLS skills; the majority of these attainments were associated with lower level skills; 3 attainments met high level skills, and no attainment overlapping with intermediate or advanced reading skills was included in the curriculum.

When the results of the SMLTC were examined, it was determined that although all the skills were not included in the curriculum but different skills of each level were included. Considering the 1999 and 2016 curricula implemented in the Irish mother language teaching process, it was concluded that the 1999 curriculum did not include any objectives that met PIRLS skills directly, while the majority of the objectives determined to be similar to those skills met the high and advanced skills. When the 2016 IMLTC, which was the other curriculum examined in the study, is taken into consideration, it was concluded that except for one of the objective expressions that were similar to PIRLS skills, all of them were at $\mathrm{E}$ and above levels; none of the intermediate skills were included in the curriculum, mostly high and advanced skills were included in the content.

When the findings were considered in a holistic way, it will be true to say that none of the curricula met the PIRLS reading skills, but that the SMLTC was relatively more comprehensive and competent. It was thought that the curriculum development studies that Singapore has systematically pursued since 1959 had a significant impact on this result. It is a fact that Singapore's studies in 1959, 1971, 1981, 1991, 2001 and 2010 have yielded positive results in improving the quality of education curricula and education. The mother language curriculum, which was currently being implemented in Singapore, was developed within the framework of the language reform initiated by the country's ministry of education, and a two-year fieldwork was carried out before the implementation of the curriculum. The ultimate goal to be achieved in the execution of these studies was stated as the future Singapore generation to have language skills at the level of competence (Loh, J. and Poh - Yi, F., 2018).

Different studies conducted in the literature support the results obtained in the research. In his study in Paris (2017) stated that the mother language curriculum of Singapore was not limited to limited skills by covering several stages of development, but it included different knowledge and high level skills to increase students' competencies and the curriculum could be accepted as a model in this sense. Sizmur, J., Ager, R., Classick, R., and Lynn, L. (2017) stated that the mother language teaching curricula of Singapore and Ireland were above the international average in terms of emphasis on reading skills and strategies in the early years 
in their studies that they compared the different variables of 7 countries successful in PIRLS, including Ireland and Singapore. In their study Yaman and Göçen (2014) compared Turkey and Singapore mother language teaching curricula in terms of "general purposes", language teaching approach"," teaching-learning process"," general outcomes of teaching","skill areas", "skill aim/objective" and "measurement -evaluation" and they reached similar results. Accordingly they indicated that Singapore mother language teaching curriculum can be an example for Turkey in terms of curriculum elements.

When the results of TMLTC are considered it is noteworthy that the curriculum had significant shortcomings in meeting the PIRLS skills. İnce and Gözütok (2018) found similar results in their studies that was conducted with different class levels, and found that the reading skill attainments in the Turkish 6-8th grade curriculum coincided with the reading skills competencies mostly in the first three levels of PISA. In their studies Demirel and Yağmur (2017), stated that in terms of high level thinking processes (HLTP) of PIRLS, both public and private school students in Turkey had low level skills and stated that it would be useful for the reorganization of the Turkish curriculum in terms of HLTP. Similarly, Batur and Ulutaş (2013) found that the attainments included in the 2006 6-8 Grades Turkish Lesson Curriculum met the lower level reading comprehension skills in PISA. As it is seen, the deficiencies determined for Turkish course curricula are still continuing. Accordingly, the 1-3th grade achievements in TMLTC are similar only to low level PIRLS skills, and it is seen as an important obstacle for students to have high level thinking and reading skills. Accordingly, the 1-3th grade attainments in the curriculum are similar to only low-level PIRLS skills, and it is seen as an important obstacle for students to have high-level thinking and reading skills.

As it is known today it is aimed to measure the knowledge and skills acquired by students in different countries in a comparative way through international exams that are held at certain intervals such as PIRLS. Apart from listing the academic achievement levels of students in the participating countries, the data obtained from these exams also provide many important tips and feedback from countries and education systems. In other words, the scores obtained from these exams are a report on the education policies being implemented by the countries. Undoubtedly, the main purpose in the presentation of these scorecards is to identify the strengths and areas open for improvement in the light of the results obtained from the participating countries, to eliminate the deficiencies in the system and to take remedial measures. Moreover, academic achievement is a key factor in promoting children's school adjustment, self-esteem, and subjective well-being (Jung et al., 2019). As mentioned before reading is one of the main factors that affect academic achievement. For this reason it is doubtless that revising and improving the mother language curriculum will not allow students to increase their academic achievementbut also it will help them to gain these affective skills.

Turkey involved PIRLS only in 2001 and ranked 51 out of 35 participating countries, taking 51 points below the international average in this exam. (Bakioğlu, 2017). When this result and the findings obtained in the research are taken from the same perspective, it can be said that the curriculum, which is one of the main determinants of success or failure in education, is not sufficient in terms of achieving the desired level of success. Accordingly, although 2018 TMLTC, which has been examined within the scope of the study, is a curriculum that has been developed and implemented recently, it is thought that there is a need to reach international skills, which are considered as a reference point for reviewing and developing. It is anticipated that through the aforementioned arrangement, the skills of recall and comprehension corresponding to the low level reading skills in TMLTC will contribute to the evaluation and creation of students and reach the high level cognitive competencies.

In this study, reading skills are examined within the scope of mother language education curricula and suggestions for these curricula are presented. However, reading skills are important for all curricula involved in learning processes. Regardless of the course, the individual's level of knowledge can be interpreted by looking at the level of reading comprehension, and no matter how much time is devoted to learning, if the 
level of reading comprehension of individuals is not high, learning on the level of knowledge cannot be realized (Egelioğlu, 1993). Many studies on the subject (Durgun, 2019; Bayat et al., 2014; Yılmaz, 2011; Göktaş, 2010; Obalı, 2009; Oluk and Başöncül, 2009; Ateş, 2008; Özdemir, 2006; Sallabaş, 2008; Sertsöz, 2003) shows that reading skills are effective not only in Turkish course but also in achieving success in different couses. Therefore, it is recommended to review the reading skills included in the curriculum of different courses with other studies. 


\section{REFERENCES}

Akyol, H. (2007). Türkçe ilkokuma yazma öğretimi. Ankara: Pegem A Yayıncılık.

Ateş, M. (2008). İlköğretim ikinci kademe öğrencilerinin okuduğunu anlama düzeyleri ile Türkçe dersine karşı tutumları ve akademik başarıları arasındaki ilişki (Doctoral dissertation). Selçuk Üniversitesi, Sosyal Bilimleri Enstitüsü.

Bayat, N., Şekercioğlu, G., and Bakır, S. (2014). Okuduğunu anlama ve fen başarısı arasındaki ilişkinin belirlenmesi. Eğitim ve Bilim, 39(176).

Bender, W., N. (2012). Öğrenme güçlüğ̈̈̈ olan bireyler ve eğitimleri. (Edt: Hakan Sarı). Ankara: Nobel.

Batur, Z. and Ulutaş, M. (2013). PISA ile Türkçe Öğretim Programındaki okuduğunu anlama kazanımlarının örtüşme düzeylerinin incelenmesi, The Journal of Academic Social Science Studies, 6(2), 1549-1563.

Campbell, J.R., Kelly, D.L., Mullis, I.V.S., Martin, M.O., and Sainsbury, M. (2001). Framework and specifications for pirls assessment 2001. Chestnut Hill, MA: Boston College.

Creswell, J. W. (2007). Qualitative inquiry E research design: Choosing among five approaches ( 2. Edition). USA: SAGE Publications.

Demirel, G., and Yağmur, K. (2017). Uluslararası PIRLS uygulamaları ölçütlerine göre Türk öğrencilerin üst düzey düşünme becerilerinin değerlendirilmesi. Dil Ĕ̆itimi ve Araştırmaları Dergisi, 3(2), 95-106.

Durgun, E., and Önder, İ. (2019). The Relationship of Science Achievement with Reading Comprehension, Graphic Reading, Problem Solving Skills in Middle School Seventh Grade Students.

Egelioğlu, V. (1993). Okuduğunu anlama düzeyinin ve öğrenme için harcanan zamanın bilişsel öğrenme düzeyine etkisi, Eğitim Bilimleri Birinci Ulusal Kongresi Bildirileri I, 24-28 Eylül 1990. Ankara.

Göktaş, Ö. (2010). Okuduğunu anlama becerisinin ilköğretim ikinci kademe matematik dersindeki akademik başarıya etkisi(Master's Thesis). İnönü Üniversitesi, Eğitim Bilimleri Enstitüsü.

Hernandez,D,J. (2012).Double Jeopardy: How Third-Grade Reading Skills and Poverty Influence High School Graduation (Baltimore, MD: Annie E. Casey Foundation).

IMLTC, Primary School Curiculum, Ireland. (1999). https://www.curriculumonline.ie/Primary date of access: 25 March 2019.

IMLTC, Primary Language Curriculum, Ireland. (2016). https://www.curriculumonline.ie/ date of access: 25 March 2019.

İnce, M and Gözütok, F.D. (2018). Türkçe 6,7,8. sınıf öğretim programının uluslararası öğrenci değerlendirme programında (PISA) yoklanan okuma becerileri açısından analizi (Zonguldak örneği). Kastamonu Ĕ̆itim Fakültesi Dergisi, 26(5), 1613-1621.

Jung, S., Choi, N., and Jung, S. (2019). The Effects of the Initial Reading Experience of Infancy on the Reading and Academic Achievement of Elementary First Graders. On Early Childhood Development (ICECD 2019), 1.

Kamhi, A. and Catts, H. (2008). The language basis of reading: Implications of classification and treatment of children with reading disabilities. In Bulter, K.\& Silliman, E. (Eds.) Speaking, Reading, and Writing in Children with Language and Learning Disabilities: New Paradigms in Research and Practice.

Kavcar, C. and Oğuzkan, F. ve Sever, S. (1995). Türkçe öğretimi. Ankara: Engin Yayınevi. 
Loh, J., and Poh-Yi, F. (2018). Implementing and sustaining language curriculum reform in Singapore primary schools. The Wiley Handbook of Teaching and Learning, 151.

Madge, J. (1965). The tools of science an analytical description of social scince techniques. Anchor Books Doubleday and Comp.

MEB. (2015). Türkçe Dersi (1-4. Sınıflar Öğretim Programı).Ankara: Devlet Kitapları Müdürlüğü.

MEB. (2018). Türkçe Dersi (1-4. Sınıflar Öğretim Programı).Ankara: Devlet Kitapları Müdürlüğü.

Mert, E. L. (2012). Anadili Eğitimi- Öğretimi Sürecinde Çocuk Yazını Ürünlerinden Yararlanma ve Masal ürüne yönelik bazı belirlemeler. Pamukkale Üniversitesi Ĕ̆itim Fakültesi Dergisi, 31, 1-12.

Mullis, I. V. S., Martin, M. O., Gonzalez, E. J., and Kennedy, A. M. (2003). PIRLS 2001 international report. Boston: International Study Center, Lynch Schhol of Education, Boston College.

Mullis, I. V. S., Martin, M. O., Kennedy, A. M., and Foy, P. (2007). PIRLS 2006 international report. Boston: International Study Center, Lynch Schhol of Education, Boston College.

Mullis, I.V.S., Martin, M.O., and Sainsbury, M. (2015). PIRLS 2016 reading framework. In Mullis, I.V.S., \& Martin, M.O. (Eds.), PIRLS 2016 assessment framework (2nd ed.). Chestnut Hill, MA: TIMSS \& PIRLS International Study Center, Boston College.

Mullis, I. V. S., and Martin, M. O. (2016). PIRLS 2016 Assessment Framework. http://timssandpirls.bc.edu/pirls2016/framework.html Date of Access: 25.01.2020

Ogle, L. T., Sen, A., Pahlke, E., Jocelyn, L., Kastberg, D., Roey, S., and Williams, T. (2003). International Comparisons in Fourth-Grade Reading Literacy: Findings from the Progress in International Reading Literacy Study (PIRLS) of 2001.

Obalı, B. (2009). Öğrencilerin Fen ve Teknoloji Akademik Başarısıyla Türkçede Okuduğunu Anlama Ve Matematik Başarıları Arasındaki İlişki (Master's Thesis). Sakarya Üniversitesi, Eğitim Bilimleri Enstitüsü.

Oluk, S. and Başöncül, N. (2009). İlköğretim 8. sınıf öğrencilerinin üstbiliş okuma stratejilerini kullanma düzeyleri ile fen-teknoloji ve Türkçe ders başarıları üzerine etkisi, Kastamonu Ĕ̆itim Dergisi, 17, 183-194.

Önkaş, N. A. (2010). Ana dili öğretimine yeni yaklaşımlar. Muğla Üniversitesi Sosyal Bilimler Enstitüsü Dergisi, (24), 121-128.

Özçelebi, O. S. and Cebecioğlu N. S.. (1990). Okuma alı̧̧kanlığı ve Türkiye, Türkiye'de okuma alışkanlığının olmaması sorunu, nedenleri ve çz̈züm yolları. İstanbul: Milliyet Yay.

Pang, E. S., Muaka, A, Bernhardt, E. B. and Kamil, M. L. (2003).Tteaching reading (educational practices series-12). Geneva: International Academy of Education, International Bureau of Education.

Paris, S.G.(2017). Suggestions to improve the indonesian literacy curriculum. faculty of languages and arts yogyakarta state university.

Russel, D.H. (1949). Reading and child devolopment", reading in the elementary school, forty eighty yearbook, the national society for the study of education, part 11., Chicago: Chicago University Press.

Rutkowski, L., Gonzalez, E., Joncas, M., and Davier, M. (2010). International large-scale assessment data: Issues in secondary analysis and reporting. Educational Researcher, 39, 142-151.

Sallabaş, M. E. (2008). İlköğretim 8. sınıf öğrencilerinin okumaya yönelik tutumları ve okuduğunu anlama becerileri arasındaki ilişki, İnönü Üniversitesi Eğitim Fakültesi Dergisi, 9(16), 141-155. 
SMLTC, English Language Syllabus, Primary\&Secondary, Singapore. (2010). https://www.moe.gov.sg/education/syllabuses/english-language-and-literature Date of access: 29 March 2019.

Sertsöz, T. (2003). İlköğretim okullarının 6. sınıflarında okuduğunu anlama davranışının kazandırılmasının matematik başarısına etkisi (Master's Thesis). Marmara Üniversitesi, Eğitim Bilimleri Enstitüsü.

Singh, M. V., Gupta, M. N., and Kulkarni, M. H. (2019). Importance of Mother Tongue in Prımary Education. IJRAR-International Journal of Research and Analytical Reviews (IJRAR), 6(1), 19-24.

Sizmur, J., Ager, R., Classick, R., and Lynn, L. (2017). PIRLS 2016 in Northern Ireland: Reading Achievement. National Foundation for Educational Research. The Mere, Upton Park, Slough, Berkshire, SL1 2DQ, UK.

Yaman, H., and Göçen, G. (2014). A comparative study on native language arts curricula of Turkey and Singapore. Ĕ̆itimde Kuram ve Uygulama, 10(4), 783-806.

Yıldırım, A. (1999). Nitel araştırma yöntemlerinin temel özellikleri ve eğitim araştırmalarındaki yeri ve önemi. Eğitim ve Bilim Dergisi, 23:112: 7- 17.

Yıldırım, A. and Şimşek, H. (2013). Sosyal bilimlerde nitel araştırma yöntemleri. Ankara: Seçkin Yayıncılık.

Yılmaz, M. (2011). İlköğretim 4. sınıf öğrencilerinin okuduğunu anlama seviyeleri ile Türkçe, matematik, sosyal bilgiler ve fen ve teknoloji derslerindeki başarıların arasındaki ilişkinin belirlenmesi. Dumlupınar Üniversitesi Sosyal Bilimler Dergisi. 29. 